Cathy Brown

DOI: 10.18290/pepsi-2019-0001

Tracey Wond*

\title{
Building Career Capital: Helping Workers to Enhance Career Mobility in Uncertain Times
}

\section{ABSTRACT}

There is evidence that organisational career role holders are changing roles more frequently. Despite this, career theories such as the career capital lens have so far neglected this role transition context. By adopting the lens of career capital theory specifically, this paper explores what aspects of career capital role holders need to facilitate their own voluntary, sideward or upward role transitions. Drawing upon an interpretivist approach and using event-based narrative interviews, this study explores the experiences of 36 business leaders who have undertaken a recent role transition within a large UK construction business. By applying this novel career capital lens, the paper empirically characterises those aspects of career capital important to internal role transitions and compares it to existing mainstream career capital theory. The study is original in that career capital has not been applied before in this increasingly important transition context. Surprisingly, whilst the study demonstrates that career capital eases transitions, it also recognises a 'dark side' - career capital aspects that hinder internal movement.

KEYWORDS: career capital, role transitions, career mobility.

* Correspondence regarding the paper should be sent to: Cathy Brown, e-mail: cathybrown@evolve.eu.com, or Tracey Wond, e-mail: t.wond@derby. ac.uk, University of Derby, College of Business, Law and Social Sciences, UK. 
Within our increasingly volatile, uncertain, complex and ambiguous (VUCA) societies, our working environment is ever more challenging (Alejandro \& Yolanda, 2015). With growing commercial pressures on organisations, a job for life is perhaps less realistic for individuals than it once was (Tulgan, 2001) meaning that transitions between roles are becoming more frequent (Kambourov \& Manovski, 2008). Further, it is widely predicted that individuals will be working for longer, 'for some into their 70s or even 80s' (Gratton \& Scott, 2017, p. 6). This changing work context brings about a need for individuals to be able to manage these transitions. For the purposes of this paper we term an individual's ability to undertake role transitions as 'career mobility' (there are varying definitions and applications of career mobility).

In 1994, DeFillippi and Arthur (1994) introduced a framework that drew together a range of non-financial, personal resources that individuals bring to their work, defined as career capital (DeFillippi \& Arthur, 1994; Arthur, DeFillippi, \& Jones, 2001). The notion of 'capital' drew from Bourdieu's capital theory, particularly the social and cultural capital aspects of Bourdieu's theory (Bourdieu, 1986). Their career capital framework (DeFillippi \& Arthur, 1994) consisted of three knowings: 'Knowing-Why', 'Knowing-How', and 'Knowing-Whom'. DeFillippi and Arthur's career capital framework (1994) has since been used extensively to understand individual and organisational change. Yet, despite its use in change contexts, career capital has been applied to few role transitions contexts (with the exception of female entrepreneurs (Terjesen, 2005) and global careers (Suutari \& Makela, 2007)).

As part of a wider study, and acknowledging opportunity for further research to explore role transitions from a career capital lens, we set about to explore whether, how and what aspects of career capital facilitated role transitions within the organisational career context. The study comprised of event-based, narrative interviews with 36 business leaders in a UK construction business. This paper presents one part of this wider study. It seeks to 
explore empirically whether career capital fits the role transition context, and seeks to answer the following questions:

1. Can career capital be applied to a role transition context?

2. Are there any shortfalls in DeFillippi and Arthur's (1994) career capital framework when exploring the role transition context?

3. What can be learned from the application of career capital to the role transition context?

The paper supports the conceptual development of career capital by exploring it in new specific contexts. By understanding shortfalls and adaptations of the career capital framework it further supports its conceptual development as well as building understanding of its potential for application. The contribution of empirical evidence is also relevant, given that extant career capital literature has thus far been predominantly conceptual. Practically, the paper may be useful to organisational managers and career/organisational development practitioners who wish to support others to manage their career mobility.

The next section will provide the theoretical context for the key concepts at the heart of this paper, namely, introducing career capital and the career mobility context. Section three then introduces and critically justifies the methodology used. The findings are then presented in section four.

\section{THEORETICAL BACKGROUND}

\section{The career mobility context}

It is argued that transitions are becoming more frequent (Chudzikowski, 2012). The nature of careers is changing and, with it, the notion of an organisational career or job for life is less realistic for individuals than it once was (Tulgan, 2001). At the same time, individuals are moving away 'from the so-called traditional, organisational career to one that is directed by individuals and unconstrained by organisational boundaries' (Kirk, 2010: 54) 
(e.g. Arthur \& Rousseau's (1996) notion of the boundaryless career). However, some researchers challenge these claims, arguing that the organisational career isn't dead and is very much alive (Baruch, 2006; Dries \& Pepermans, 2008).

The increasing frequency of role transitions gives rise to several challenges for researchers, individuals (as career holders) and HRD and careers professionals. Role transitions vary in nature (Schlossberg, 1984) and can include transitioning between or within an employer ( $\mathrm{Ng}$, Sorensen, Eby \& Feldman, 2007), moving within or between functions (Nicholson and West, 1988) or moving upwards, side-wards or downwards within the organisational structure or hierarchy ( $\mathrm{Ng}$ et al., 2007). The varying nature of transitions makes them complex to manage, and is likely to influence the level of challenge faced by the individual (Chudzikowski, 2012).

Role transitions have been identified as stressful for individuals (Baruch, 2006), requiring both physical and mental adjustments to routines, networks, training needs, identity and attitude (Ashforth \& Saks, 1995; Clarke, 2009; Ibarra \& Barbulescu, 2010). For some, transitions may expose fragility, prompting the need for introspection, re-evaluation and the creation of new career narratives (Clarke, 2009). In the case of business leaders (where the stakes are invariably higher), with increased notoriety and visibility, these transitions are argued to be more challenging and stressful (Ibarra \& Barbulescu, 2010). Consequently, being able to manage role transitions (in other words build career mobility), is becoming increasingly relevant (Baruch, 2006).

\section{Career capital}

DeFillippi and Arthur's career capital framework (DeFillippi \& Arthur, 1994) (see Table 1), comprises three knowings - from which 'intelligent careers are made' according to Arthur, Claman and DeFillippi (1995, p. 19). Their career capital framework is relatively generalist, applicable to career management across 
different contexts. 'Knowing-Why' career capital relates to motivation and personal meaning which may provide the owner with energy, a sense of purpose and identification with work (Inkson \& Arthur, 2001). 'Knowing-How' or human capital/cultural capital provides an individual with the work-related skills, knowledge and understanding needed to perform well (DeFillippi \& Arthur, 1994). 'Knowing-Whom' suggests social capital and refers to the value of networks, relationships and contacts both inside and outside of our professional lives (DeFillippi \& Arthur, 1994). Such relationships are claimed to be the glue that holds everything together in our social world and are fundamental to a successful intelligent career (Arthur, Khapova, \& Richardson 2017). These three 'knowings' were regarded as the currency of an individual's career development (Inkson \& Arthur, 2001).

Table 1. DeFillippi and Arthur's (1994) Individual Career Capital Theoretical Framework.

\begin{tabular}{|c|c|c|}
\hline Knowing Why & Knowing How & Knowing Whom \\
\hline $\begin{array}{l}\text { Career motivation } \\
\text { Personal meaning } \\
\text { Identification }\end{array}$ & $\begin{array}{l}\text { Career relevant skills } \\
\text { Job-related knowledge }\end{array}$ & $\begin{array}{l}\text { Career relevant networks, including } \\
\text { networks with key customers and } \\
\text { suppliers } \\
\text { Leveraging firm's reputation } \\
\text { Networks of casual contacts, includ- } \\
\text { ing family, friends, colleagues, } \\
\text { fellow alumni and outside teachers } \\
\text { and mentors }\end{array}$ \\
\hline
\end{tabular}

Note. Adapted from DeFillippi and Arthur (1994, p. 308).

Arthur et al.'s (2001) career capital theoretical framework can be operationalised relatively easily and emphasises the ease of career capital development, both advantages over rival theories. Whilst Arthur et al.'s framework has been applied extensively within the arena of organisational and individual change, there 
has been only few efforts to apply it within the role transition context, namely: the career capital required by female entrepreneurs to transition from a corporate to self-employed setting (Terjesen, 2005), and the career capital generated through global careers moves (Suutari \& Makela, 2007).

More broadly, the notion of career capital holds much strength. It is grounded in Bourdieusian theory. Firstly, such foundations are recognised through both the inclusion of social capital ('Knowing-Whom') and embracing the notion of convertibility (where capital can circulate and convert to new capital forms) (Bourdieu, 1986). In other words, capital can be traded to access additional capital forms. Secondly, Bourdieu's notion of field holds relevancy (or locality, in this case the new role and team), along with symbolic capital (or perceived value of capital, in this case perceived value of career capital) (Bourdieu, 1986). In addition, career capital is anchored in scant but robust empirical evidence, has broad conceptual range and is significant in dynamic global business contexts (Tempest \& Coupland, 2016).

Through the course of their career, individuals can build and use their career capital (Dickmann, Suutari, Brewster, Makela, Tanskanen, \& Tornikoski, 2016), being described as the value created through career position improvements within organisations and the wider labour market (Lamb \& Sutherland, 2010).

\section{RESEARCH METHODOLOGY}

This article draws upon learning from a wider doctoral study which explores the career capital that business leaders need to facilitate role transitions within an organisation within the UK. By aiming to understand the business leaders' role transition experiences and to bring meaning through in-depth interviews, an interpretivist methodological approach was taken. The study uses a case study approach comprising face-to-face, event-based 
narrative interviews with 36 business leaders who had recently (within the past 3 years) made internal, voluntary, sideward or upward role transitions in a UK-based construction company. Here, business leaders were defined as members of the three leadership groups: Executive, Leadership Group, Business Deployment Group. This approach mirrored the specification applied within the case organisation. The interviews explored aspects that had supported and hindered internal role transitions, and the business leaders' identification of additional support they perceived might have helped them. By adopting a case study design, it lends itself to bringing in-depth understanding to previously under-explored, complex, particular real-life phenomenon (Gaya and Smith, 2016), such as business leaders' role transition experiences within an organisation. Such understanding can lead to the creation of context-dependent knowledge (Flyvbjerg, 2011) and a source of expertise and insight (Yin, 2009, 2012), that can both stimulate learning and be transferrable to new situations (Hyett, Kenny \& Dickson-Swift, 2014). In addition, through choosing event-based narrative interviewing, participants were able to access personal experiences more deeply through supporting the chronological connectivity (Saunders, Lewis, \& Thornhill, 2012) and causal relationships between reified constructs (Watson, 2009), for example role transitions and career capital. 40 hours of interviews were conducted.

Recognised as a useful approach when exploring something not explored before (Boyatzis, 1982), an iterative analytical approach was undertaken (see Figure 1).

In this context, iterative is defined as the continual movement between the analytical processing of the data, the sense-making of the data through journaling and development of field notes and the further reviewing of the literature. After being recorded and transcribed, interview transcriptions were thematically analysed for enablers and barriers for such role transitions, along with required additional support. A visual map was created for each 


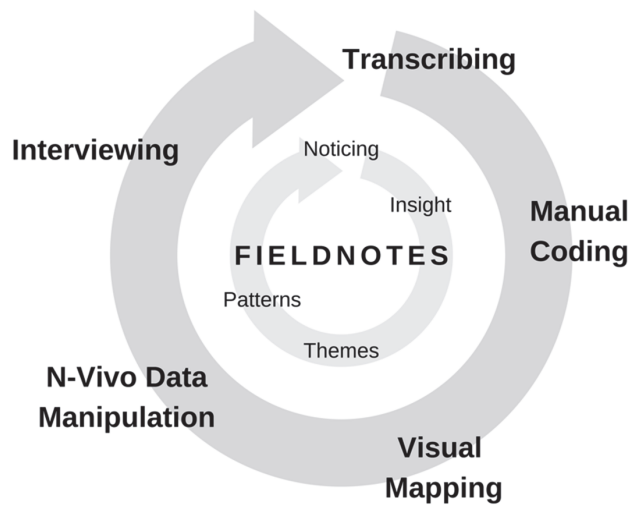

Figure 1. An Iterative Analytical Approach.

Source: own study.

business leader to illustrate the interconnectivity between what helped and hindered their role transition experiences. Following manual thematic coding, NVivo was used to support further data interrogation. In addition, running, meditation, journaling and the creation of field notes helped to facilitate sense-making of the data and the conceptual connection of thoughts and observing of patterns and differences, where 'insights come up on their own timetable' (Kabat-Zinn, 2002, p. 69).

Finally, Golden-Biddle and Locke's (1993) three criteria of authenticity, plausibility and criticality were selected as research quality indicators. More specifically, authenticity is illustrated through the researcher's deep understanding of what was taking place in the organisation at the time of the research; plausibility is shown by linking into issues that are of interest to other researchers; criticality is demonstrated through encouraging readers to question their assumptions thereby offering something genuinely novel. 
RESULTS

\section{The relevance of career capital in the transition context}

The notion of career capital, and its comprising aspects, appeared to fit the transition experiences described by business leaders (as respondents) well. All 36 business leaders described aspects that supported their role transition and that were congruent with the career capital framework. Such career capital aspects were drawn upon by business leaders to support their role transition in numerous ways, including winning the role opportunity, undertaking role activities soon after the transition and overcoming obstacles.

For example, Garry illustrated how his influencing skills helped him to win the chance of gaining an interview within a different functional team:

I put [my] application in and started my aggressive campaign! So I made appointments with pretty much every member of the leadership team [...]. I took in 1\% of what they said but it was all about appearances for me [...] I needed to give myself competitive advantage [...] that worked!

This demonstrated how the career-relevant skill of influencing ('Knowing-How') helped to open up new role transition opportunities within different functions within the organisation.

Supporting the notion of how career capital can facilitate transitions, Isaac's career-relevant experience enabled him to take on some of the new role's activities with ease:

I think past experience is part of it [...]. It wasn't coming into a fresh role, so it wasn't all alien. So I knew the basics of it and the proportion of customers. I knew how the deals were structured and I knew what the internal processes were like. So all of that was relatively straight-forward. 
Drawing upon such experience ('Knowing-How') helped Isaac to 'enjoy' the transition and 'feel more confident in growing into this new role'.

Phil was able to draw upon a recent qualification in discussion and, in turn, influence senior managers:

I had done a Masters in Organisational Innovation and I had majored on cultural transition [...] so whenever I was talking to the senior management around the project and the challenges that I was facing in the project, I was very able to say this is happening ... That awareness and the language that allowed me to I guess look and sound a lot different ... I would use that as leverage to really change the attitude that the organisation had.

Phil's qualification not only provided additional 'know-how', but also demonstrated that career capital can be developed further through the role transition experience. In his case, akin to Bourdieu's (1986) notion of convertibility (where capital can circulate and convert to new capital forms), Phil began to build career capital in respect of 'Knowing-Whom' (in being able to better impact stakeholders).

\section{IMPORTANCE OF THE 'SELF'}

Of these career capital aspects described by the business leaders, three broad categories emerged, with the importance of self-knowledge, career-relevant knowledge and networks surfacing strongly. These categories differed from earlier constructs of career capital. Business leaders spoke less of their reasoning behind undertaking roles transitions (knowing why), and instead spoke more about knowing themselves. In relation to knowing themselves, the importance of knowledge, self-belief and personal drive emerged frequently. 
For illustration, Helen illustrated how her ability to challenge senior people helped her to influence the approach taken:

Some of these things you have to say no to. So it is having strength of character to say to the most senior manager of the team in the business: 'Actually we are not going to do that!'

This demonstrated how having the self-confidence ('KnowingSelf') helped to speak out and assert herself with others, including organisational stakeholders. In addition, Darren showed how having drive helped him to win the opportunity:

'We want it by 9am the tomorrow morning.' [...] So I spent a good 7-8 hours on it, had a late night and put a lot of effort into it and produced a 6-7 page document of all of my answers [...] I would analyse in terms of the business what does that mean how could they improve it and properly analyse the data. And I know that was what got me the job over the others.

Darren's motivation illustrates how having the determination ('Knowing-Self') helped to win the new role opportunity.

The emergence of self-knowing through the interviews prompts us to revisit the career capital framework of DeFillippi and Arthur and suggest a modification - the replacement of knowing 'why' with knowing 'self'. Table 2 summarises this modification in the form of a revised career capital theoretical framework. The notion of self-knowing is not in itself new to career theory, for instance Hirsh (2008) identified the importance of self-knowledge in her individual career planning model. 
Table 2. Revised Career Capital Theoretical Framework.

\begin{tabular}{|c|c|c|}
\hline Knowing Self & Knowing How & Knowing Whom \\
\hline $\begin{array}{l}\text { An understanding of self } \\
\text { and belief in own ability } \\
\text { with personal drive to } \\
\text { want to make things } \\
\text { happen, including } \\
\text { - self-awareness, } \\
\text { - self-confidence, } \\
\text { - motivation. }\end{array}$ & $\begin{array}{l}\text { Having career-relevant } \\
\text { experience, knowledge, } \\
\text { expertise, qualifications } \\
\text { and flexible skill set, } \\
\text { including } \\
\text { - adaptability, } \\
\text { - critical thinking, } \\
\text { - influence, } \\
\text { - initiative. }\end{array}$ & $\begin{array}{l}\text { Having an internal work } \\
\text { network and external family } \\
\text { network with associated } \\
\text { resources, and a personal } \\
\text { reputation within these } \\
\text { networks, including } \\
\text { - colleagues, } \\
\text { - direct reports, } \\
\text { - previous line manager, } \\
\text { - peers. }\end{array}$ \\
\hline
\end{tabular}

Source: own study.

This revised career capital framework holds additional advantages over its predecessor. First and foremost, it is empirically-based rather than having a diffuse conceptual basis; by focusing on organisational role transitions, it provides insight into a previously unexplored area. Secondly, this new career capital framework offers better fit to a specific role transition context, emphasising the need for a: broad, flexible skill set, intra-organisational network and the access of potential resources available through such structures, echoing Bourdieu's social capital stance (Bourdieu, 1986).

\section{Career capital - the dark side}

Other interesting and unexpected findings emerged from our findings. Firstly, the vast majority (35) of the 36 business leaders described how career capital also hindered their role transition experience, acting as a liability. Firstly, having too much 'Knowing-Self', 'Knowing-How' and 'Knowing-Whom' career capital impeded their transition. For example, Jim found that having too much career-relevant job knowledge ('Knowing-How') led him to take things for granted and to not assess the situation that he was walking into: 
I am wondering if the downside is that if you go in there being familiar with it, you don't go through that process of, I will give it three months and I will write my report of what is wrong and what is right. I haven't formally done that in my head, I have known it from the off; I have known the sort of things that I want to change.

Jim felt that this abundance of career-relevance knowledge may have held back his thinking and forming of his change agenda.

Secondly, the barriers caused by 'Knowing-Whom' were more complex in nature. 15 business leaders experienced having misunderstanding, and in some situation's conflicts, within a range of their contacts concerning a range of topics, including: role clarity, perceived priorities and approach for vision delivery. For example, James discovered that his previous line manager was upset about him moving within the business. As a result, their relationship suffered and James' career capital (relationship with previous line manager) was eroded:

My previous boss was a bit distraught I think because I wanted to leave that role, not because I was so bloody brilliant but because it left him with a problem. [...] So I got kicked around the room a few times for no real reason other than he didn't like it and he was having a bit of a stomp.

James described how the erosion of this relationship impacted his role transition experience which he described as 'at times frustrating'.

Finally, rather than being static, these empirical findings show how career capital acts as a dynamic resource through the individuals' role transition. For example, through changing roles and teams, the business leaders found that their career capital portfolio changed in perceived value, illustrating the relevancy of Bourdieu's notion of field (or locality, in this case the new role 
and team) and symbolic capital (or perceived value of capital, in this case perceived value of career capital) (Bourdieu, 1986).

For illustration Garry discovered that by changing functions within the same building, his reputation suffered:

I had to go and press the reset button and jolt him out of whatever image he had of me [...] being [...] very data drive and being very process reliant.

I had to work massively hard [...]. It was evident in her questions that she was asking 'Is this is this a [function] guy?' and 'Are we going to have a functional [...] clockwork worker?' because that is not what they wanted [...] they wanted someone different, so I had to prove that I was somebody different.

So, Garry had to work hard at reforming a more suitable reputation for this new function and winning over its stakeholders.

The emergence of a 'dark-side' of career capital is novel in itself and worthy of further exploration. Career management literature is arguably weighted towards identifying how individuals can be supported and developed, caution about the weaknesses of having 'too much of a good thing' are less evident (Brown, 2018).

\section{CONCLUSION}

Our paper sought to explore, using our research findings, whether career capital fitted the role transition context. We found that in the main our findings were congruent with DeFillippi and Arthur's framework (1994), with knowing whom and knowing how emerging strongly in our interview data. To answer our first research question (Can career capital be applied to a role transition context?), we certainly found that career capital as a lens could be applied to this context, and DeFillippi and Arthur's framework 
in particular was conceptually and stylistically fitting in the most part. We found that aspects of career capital facilitated business leaders' organisational transitions and enabled the overcoming of barriers.

In response to research question two (Are there any shortfalls in DeFillippi and Arthur's (1994) career capital framework when exploring the role transition context?), we did find any shortfalls when applied within the role transition context. The notion of 'Knowing-Why' was less important when exploring barriers and enablers to role transitions. Our new career capital framework emphasised the importance of 'Knowing-Self' within such setting, with less relevancy for career interests and identification. Also, an organisational transition setting requires greater specificity of: flexible skills set ('Knowing-How') as well as an internal organisational network with associated resources ('Knowing-Whom'), with less importance given to networks outside of the organisation.

In respect of our third research question (What can be learned from the application of career capital to the role transition context?), we were able to revise DeFillippi and Arthur's career capital framework for the specific role transition context. The themes emerging through our interviews indicated that knowing whom, how and self were important in the role transition context - in our case study - business leaders making role transitions in a construction business. The adaptation of this framework, generated from our research findings, results in the conceptual development of career capital theory. It begins to explore how a broad lens such as career capital can be applied in specific contexts. Moreover, such empirical findings provide conceptual value for career researchers where the distinctions and characteristics of career capital have been clarified within the previously under-explored area of organisational role transitions. Other interesting and unexpected findings have surfaced through our research study, including how career capital can indeed impede role transitions, as well as change in value through the changing of organisational location. 
Such empirical findings enable organisational managers and practitioners within the fields of career counselling and career education to provide support to role holders and clients, respectively. In particular, organisational managers can provide role transition support through helping to: anticipate forthcoming barriers (Ibarra, 2002), sign-post to colleagues who have undertaken similar role transitions and can provide coaching (Gonin, Napiersky, \& Thorsell, 2011) and mentoring support (DeFillippi \& Arthur, 1994). Furthermore, career practitioners can apply learnings from this empirical research to support clients to build their career mobility. Such transition support can comprise: anticipating how career capital changes in perceived value, foreseeing how career capital may develop or erode through such an experience and exploring how the Knowing-How configuration and patterns of relationships may evolve (Schuller, Baron, \& Field, 2000).

In terms of future avenues of research, firstly, it may be pertinent to undertake the same research study but with a different case organisation(s) and population. The single case context was vital to understand career capital in detail but does represent a study limitation. Different contexts may expose variations in how aspects such as organisational culture and organisational career management (whether from HRD/HRM professionals, line managers or others) influence career capital elements. Exploring the application of career capital beyond business leaders may also be insightful to further our understanding. Secondly, it may be useful to broaden the scope of the enquiry to explore how different motivations towards role transitions impact career capital needs. Different transition dimensions, for example: involuntary transitions and international transitions, are likely to create specific individual challenges (Schlossberg, 1984).

Finally, in light of the changing work context where transitions are becoming the norm, insights created through this research study will add value to organisational managers and career practitioners in supporting individuals to build their organisational 
career mobility, as well as career researchers in conceptualising career capital within the organisational transition setting.

\section{REFERENCES}

Alejandro, R., \& Yolanda, R. (2015). Metaphors for today's leadership: VUCA world, millennials and 'Cloud Leaders'. Journal of Management Development, 34(7), 854-866.

Arthur, M. B., Claman, P. H., \& DeFillippi, R. J. (1995). Intelligent enterprise, intelligent careers. Academy of Management Executive, 9(4), 7-20.

Arthur, M. B., DeFillippi, R. J., \& Jones, C. (2001). Project-based learning as the interplay of career and company non-financial capital. Management Learning, 32 (1), 99-117.

Arthur, M. B., Khapova, S. N., \& Richardson, J. (2017). An intelligent career: taking ownership of your work and your life. Oxford: Oxford University Press.

Arthur, M. B., \& Rousseau, D. M. (Eds.). (1996). The boundaryless career: A new employment principle for a new organisational era. Oxford: Oxford University Press.

Ashforth, B. E., \& Saks, A. M. (1995). Work-role transitions: A longitudinal examination of the Nicholson model. Journal of Occupational and Organisational Psychology, 68, 157-175.

Baruch, Y. (2006). Career development in organisations and beyond: Balancing traditional and contemporary viewpoints. Human Resource Management Review, 16, 125-138.

Bourdieu. P. (1986). The forms of capital. In I. Szeman \& T. Kaposy (Eds.), Cultural theory: An anthology. Chichester: Wiley-Blackwell.

Boyatzis, R. E. (1982). The competent manager: A model for effective performance. New York, NY: John Wiley and Sons.

Brown, C. A. (2018). Business leaders: Career capital and role transition (Unpublished doctoral dissertation). University of Derby, Derby, England.

Chudzikowski, K. (2012). Career transitions and career success in the 'new' career era. Journal of Vocational Behavior, 81(2), 298-306.

Clarke, M. (2009). Plodders, pragmatists, visionaries and opportunists: Career patterns and employability. Career Development International, 14(1), 8-28.

DeFillippi, R. J., \& Arthur, M. B. (1994). The boundaryless career: A competencybased perspective. Journal of Organisational Behaviour, 15, 307-324.

Dickmann, M., Suutari, V., Brewster, C., Makela, L, Tanskanen, I., \& Tornikoski, C. (2016). The career competencies of self-initiated and assigned expatriates: 
Assessing the development of career capital over time. The International Journal of Human Resource Management, 27, 1-25.

Dries, N., \& Pepermans, R. (2008). Real high-potential careers: An empirical study into the perspectives of organisations and high potentials. Personnel Review, 37(1), 85-108.

Flyvbjerg, B. (2011). Case study. In N. K. Denzin \& Y. S. Lincoln (Eds.). The sage handbook of qualitative research. London: Sage, 301-316.

Gaya, H. J., \& Smith, E. E. (2016). Developing a qualitative single case study in strategic management realm: An appropriate research design? International Journal of Business Management and Economic Research, 7(2), 529-538.

Golden-Biddle, K., \& Locke, K. (1993). Appealing work: An investigation of how ethnographic texts convince. Organisation Science, 4(2), 595-616.

Gonin, D., Napiersky, U., \& Thorsell, J. (2011). Innovation in leadership development. In W. H. Mobley, M. Li, \& Y. Wang (Eds.). Advances in Global Leadership (Advances in Global Leadership, Volume 6, pp. 155-215). Bingley: Emerald.

Gratton, L., \& Scott, A. (2017). The 100-year life. Living and working in an age of longevity. London: Bloomsbury.

Hyett, N., Kenny, A., \& Dickson-Swift, V. (2014). Methodology or method? A critical review of qualitative case study reports. International Journal on Qualitative Studies on Health and Well-being, 9, 23606.

Ibarra, H. (2002, December). How to stay stuck in the wrong career. Harvard Business Review, 40-47.

Ibarra, H., \& Barbulescu, R. (2010). Identity as narrative: Prevalence, effectiveness and consequences of narrative identity work in macro work role transitions. Academy of Management Review, 35(1), 135-154.

Inkson, K., \& Arthur, M. B. (2001). How to be a successful career capitalist. Organisational Dynamics, 30(1), 48-61.

Hirsh, W. (2008). Career development in employing organisations: Practices and challenges from a UK perspective. London: Institute for Employment Studies. https://www.employment-studies.co.uk/system/files/resources/files/ hrp1.pdf

Kambourov, G., \& Manovski, I. (2008). Rising occupational and industry mobility in the United States: 1968-97. Industrial Relations, 37(2), 41-79.

Kabat-Zinn, J. (2002). Meditation is about paying attention. Reflections, 3(3), 68-71. Lamb, M., \& Sutherland, M. (2010). The components of career capital for knowledge workers in the global economy. The International Journal of Human Resource Management, 21(3), 295-312.

Kirk, S. (2010). Global mobility choices: A study of international leaders (Doctoral dissertation). Nottingham Trent University, Nottingham, UK. 
Ng, T. W. H., Sorensen, K. L., Eby, L. T. \& Feldman, D. C. (2007). Determinants of job mobility: A theoretical integration and extension. Journal of Occupational and Organisational Psychology, 80, 363-386.

Nicholson, N., \& West, M.A. (1988). Managerial job change: Men and women in transition. Cambridge: Cambridge University Press.

Saunders, M., Lewis, P., \& Thornhill, A. (2012). Research methods for business students. Essex: Pearson.

Schlossberg, N. K. (1984). Counselling adults in career transition. New York: Springer.

Schuller, T., Baron, S., \& Field, J. (2000). Social capital. A review and critique. In S. Baron, J. Field, \& T. Schuller (Eds.), Social capital: critical perspectives. New York: Oxford University Press, 1-38.

Suutari, V., \& Makela, K. (2007). The career capital of managers with global careers. Journal of Managerial Psychology, 22(7), 628-648.

Tempest, S., \& Coupland, C. (2016). Lost in time and space: Temporal and spatial challenges facing older workers in a global economy from a career capital perspective. The International Journal of Human Resource Management, 1-25.

Terjesen, S. (2005). Senior women managers' transition to entrepreneurship, Career Development International, 10(3), 246-259.

Tulgan, T. (2001). Winning the talent wars, Employment Relations Today, 28(2), 37-51.

Watson, T. J. (2009). Narrative, lie, story and manager identity: A case study in autobiographical identity work. Human Relations, 62(3), 425-452.

Yin, R. (2009). Case study research: Design and methods (4th edition). Thousand Oaks, CA: Sage.

Yin, R. (2012). Application of case study research (3rd edition). Thousand Oaks, CA: Sage. 